\title{
HUBUNGAN KARAKTERISTIK, MOTIVASI DAN KOMPETENSI TERHADAP PRODUKTIVITAS KERJA PENYULUH PERTANIAN DI KOTA BENGKULU
}

\author{
CORRELATION OF CHARACTERISTICS, MOTIVATION, AND \\ COMPETENCIES OF AGRICULTURAL EXTENSION AGENTS TO \\ THEIR WORK PRODUCTIVITY IN BENGKULU CITY
}

\author{
M. Ali Hanafiah, Witman Rasyid, Agus Purwoko \\ Program Pascasarjana Magister Agribisnis Fakultas Pertanian Universitas \\ Bengkulu
}

\begin{abstract}
The objective of this research is to analyze the correlation of the agricultural agents' characteristics, motivation and competence to their work productivity. This research was conducted in February through April 2013 and used census methods. The study population was defined as many as 33 people of 45 people from the extension of existing civil servants. Data analysis was done by using Product Moment Pearson procedure. The results showed that: 1) some of the agents' characteristics were correlated significantly with their job productivity, there were period of employment, training, agricultural area in the region of agriculture extension, 2) Some factors of the agents' motivation were correlated significantly with their job productivity. There are recognition, salary and reward. 3) Some factors of the agents' competencies were correlated significantly with their job productivity. There are planning, implementating, evaluation of agriculture extension, and communication skills real contact with the work productivity of agricultural extension. 4) Work productivity level of agricultural extension agents still not yet good ("low" category) because four of five factors work productivity as method extension, extension materials and increased knowledge and skills of farmers were low.
\end{abstract}

Keywords: Agricultural Extension Agent, Characteristics, Motivation, Competence, Productivity

\section{PENDAHULUAN}

Pembangunan pada hakekatnya ialah upaya mencapai taraf hidup rakyat yang lebih baik sesuai dengan nilai-nilai yang berlaku. Pembangunan pertanian merupakan bagian dari pembangunan nasional yang menitikberatkan pada peningkatan kesejahteraan petani dan keluarganya. Hubeis (2007) menyatakan "Penyuluhan sebagai proses pembelajaran (pendidikan nonformal) yang ditujukan untuk petani dan keluarganya memiliki 
peran penting di dalam pencapaian tujuan pembangunan bidang pertanian. Anonim (2010) menjelaskan bahwa terdapat tiga tujuan utama dalam penyuluhan yakni bertani lebih baik (better farming), berusahatani lebih baik (better business) dan mencapai kehidupan yang lebih baik (better living).

Dalam rangka mencapai tujuan utama penyuluhan tersebut dibutuhkan penyuluh dengan kinerja baik, yang tercermin dari produktivitas kerjanya yang tinggi. Sapar (2011) menyatakan "kemampuan penyuluh untuk mewujudkan kinerja dalam melaksanakan semua tugas tersebut dipengaruhi banyak macam faktor, baik faktor internal maupun faktor eksternal".

Faktor internal adalah kompetensi, motivasi, kemandirian dan karakteristik penyuluh. Karakteristik atau ciri individu merupakan sifat-sifat atau atribut yang melekat pada individu yang berhubungan dengan aspek kehidupan seperti umur, jenis kelamin, status sosial, agama dan lain-lain. Kompetensi seorang penyuluh pertanian diawali dengan memahami dan menguasai tugas pokoknya. Penguasaan terhadap tugas pokok merupakan hal yang mutlak bagi seorang penyuluh karena akan mempengaruhi kinerjanya. Lebih lanjut, dari beberapa penelitian terdahulu dinyatakan bahwa kinerja penyuluh relatif rendah. Menurut Widiyati (Hubeis, 2007), rataan pekerja yang termotivasi akan menggunakan $80-90 \%$ kemampuan dalam bekerja. Penyuluh yang tidak termotivasi hanya memakai 20-30\% kemampuannya dalam bekerja.

Berdasarkan uraian di atas penulis tertarik untuk melakukan penelitian mengenai hubungan karakteristik, motivasi dan kompetensi terhadap produktivitas kerja penyuluh pertanian di Kota Bengkulu

\section{METODE PENELITIAN}

Penelitian ini dirancang berbentuk survei dengan penjelasan (eksplanatory research), yaitu menjelaskan pengaruh dan hubungan antara peubah-peubah penelitian, dan dilaksanakan di Kota Bengkulu, Provinsi Bengkulu. Penentuan lokasi penelitian dipilih secara sengaja. Penelitian dilaksanakan pada bulan Februari sampai bulan April 2013. Populasi dari penelitian ini adalah 33 orang penyuluh pertanian PNS di Kota Bengkulu dan yang memiliki wilayah kerja.

Untuk mendiskripsikan peubah karakteristik, motivasi, dan kompetensi penyuluh serta tingkat produktivitas penyuluh maka masing-masing peubah diklasifikasikan ke dalam tiga kategori yaitu rendah, sedang, dan tinggi. Untuk melihat hubungan antara peubah karakteristik, motivasi dan kompetensi dengan produktivitas kerja penyuluh digunakan uji statistik korelasi pearson. 


\section{HASIL DAN PEMBAHASAN}

\section{Distribusi Penyuluh berdasarkan Karakteristik}

Hasil penelitian mengenai distribusi penyuluh berdasarkan karakteristik di tunjukkan pada tabel 1 berikut.

Tabel 1. Distribusi Penyuluh Menurut Karakteristik

\begin{tabular}{llccc}
\hline $\begin{array}{c}\text { Peubah } \\
(\mathrm{X} 1)\end{array}$ & \multicolumn{1}{c}{ Kategori } & $\begin{array}{c}\text { Jumlah } \\
\text { (orang) }\end{array}$ & Mean & Persentase (\%) \\
\hline Pendidikan & Rendah (SPMA) & 1 & & 3,00 \\
& Sedang (D3) & 7 & 15,67 & 21,20 \\
& Tinggi (D4/S1) & 25 & & 75,80 \\
\hline Pelatihan & Rendah (1-10 kali) & 14 & & 42,42 \\
& Sedang (11-20 kali) & 12 & 13,52 & 36,36 \\
& Tinggi (21-30 kali) & 7 & & 21,21 \\
\hline Masa kerja & Rendah (1-11 tahun) & 10 & & 30,30 \\
& Sedang (12-23 tahun) & 6 & 18,12 & 18,18 \\
& Tinggi (24-33 tahun) & 17 & & 51,52 \\
\hline Jumlah Kelompok & Sedikit (3-7 klp) & 15 & & 45,45 \\
tani binaan & Sedang (8-12 klp) & 13 & 8,18 & 39,39 \\
& Banyak (13-17 klp) & 5 & & 15,15 \\
\hline Luas lahan pertanian & Sempit (0-126 ha) & 22 & & 66,67 \\
wilayah kerja & Sedang (127-253 ha) & 7 & 102,33 & 21,21 \\
& Luas (254-380 ha) & 4 & & 12.12 \\
\hline
\end{tabular}

Sumber: Data primer diolah (2013)

Mayoritas pendidikan penyuluh pertanian di Kota Bengkulu adalah sarjana karena kemudahan akses untuk melanjutkan pendidikan di perguruan tinggi tanpa harus meninggalkan tugas. Mayoritas penyuluh mengikuti pelatihan dengan frekuensi yang rendah, karena kegiatan pelatihan yang dilaksanakan baik oleh pemda maupun pemerintah pusat terbatas. Penyuluh Kota Bengkulu didominasi oleh penyuluh senior yang rata-rata pindahan dari kabupaten dalam Provinsi Bengkulu, dan pengangkatan penyuluh baru di Kota Bengkulu baru dimulai pada tahun 2009.

Seiring perkembangan Kota Bengkulu maka penyusutan lahan pertanian tidak dapat dihindari. Wilayah binaan mayoritas berlahan sempit sehingga jumlah kelompok tani binaan pun sedikit dan didominasi kelompok pengolahan hasil perrtanian.

\section{Distribusi Penyuluh berdasarkan Tingkat Motivasi}

Keinginan berprestasi penyuluh Kota Bengkulu tinggi karena mayoritas penyuluh bersikap positif terhadap pekerjaannya, dan berusaha melakukan 
yang terbaik dalam menyelesaikan tugas. Pengakuan dan penghargaan yang tinggi diperoleh penyuluh rata-rata dari masyarakat dan petani binaannya, sedangkan dari institusi sendiri rata-rata penyuluh menjawab netral atau biasa saja. Pada aspek gaji/imbalan penyuluh-penyuluh baru masih optimis akan mendapat gaji dan imbalan yang setimpal dengan kinerjanya. Bagi penyuluh yang lebih senior rata-rata menjawab netral bahkan memiliki rasa pesimis terhadap gaji dan imbalan yang berkaitan dengan kinerjanya. distribusi penyuluh berdasarkan tingkat motivasi tersaji pada Tabel 2 .

Tabel. 2 Distribusi Penyuluh Menurut Tingkat Motivasi

\begin{tabular}{lcccc}
\hline $\begin{array}{c}\text { Peubah } \\
(\mathrm{X} 2)\end{array}$ & Kategori & $\begin{array}{c}\text { Jumlah } \\
\text { (orang) }\end{array}$ & Mean & $\begin{array}{c}\text { Persentase } \\
(\%)\end{array}$ \\
\hline Prestasi & Rendah (skor 4-6) & 0 & & 0,00 \\
& Sedang (skor 7-9) & 8 & 10,79 & 24,24 \\
& Tinggi (skor 10-12) & 25 & & 75,76 \\
\hline Pengakuan/penghargaan & Rendah (skor 7-11) & 1 & \multirow{2}{*}{16,24} & 3,03 \\
& Sedang (skor 12-16) & 18 & & 42,45 \\
& Tinggi (skor 17-21) & 14 & & 30,30 \\
\hline Gaji/imbalan & Rendah (skor 6-9) & 10 & \multirow{2}{*}{10,91} & 48,48 \\
& Sedang (skor 10-13) & 16 & & 21,22 \\
\hline
\end{tabular}

Sumber: Data primer diolah (2013)

\section{Distribusi Penyuluh berdasarkan Tingkat Kompetensi}

Hasil penelitian mengenai distribusi penyuluh berdasarkan Tingkat kompetensi tersaji pada Tabel 3. Terdapat kebijakan yang mengharuskan setiap penyuluh untuk melaksanakan persiapan penyuluhan. Penyusunan programa dan rencana kerja tahunan merupakan syarat pencairan biaya operasional penyuluh, sehingga penyuluh terbiasa dan terlatih melaksanakan persiapan penyuluhan. Pelaksanaan penyuluhan merupakan tugas sehari-hari setiap penyuluh, mulai dari mempersiapkan materi, metode, melaksanakan penyuluhan, hingga menumbuhkembangkan kelompok tani. Kompetensi ini terasah karena menjadi kebiasaan dan telah dilaksanakan oleh penyuluh.

Penyuluh di Kota Bengkulu hanya 18,18\% yang mampu melaksanakan kegiatan evaluasi dengan baik. Hal ini karena tidak ada kebijakan yang mengharuskan penyuluh untuk menyusun evaluasi. Selain itu kegiatan evaluasi dianggap rumit dan menghasilkan nilai angka kredit yang kecil. Sedangkan pada pengembangan profesi umumnya kegiatan yang sering dilakukan penyuluh berupa membuat terjemahan/saduran di bidang pertanian yang tidak dipublikasikan, dan hanya lima orang penyuluh yang mampu membuat karya tulis ilmiah dengan baik. 
Tabel 3. Distribusi Penyuluh Menurut Tingkat Kompetensi

\begin{tabular}{|c|c|c|c|c|}
\hline $\begin{array}{c}\text { Peubah } \\
(\mathrm{X} 3)\end{array}$ & Kategori & $\begin{array}{l}\text { Jumlah } \\
\text { (orang) }\end{array}$ & Mean & Persentase (\%) \\
\hline \multirow[t]{3}{*}{ Persiapan penyuluhan } & Rendah (skor 5-8) & 3 & \multirow{3}{*}{12,18} & 9,10 \\
\hline & Sedang (skor 9-12) & 14 & & 42,42 \\
\hline & Tinggi (skor 13-16) & 16 & & 48,48 \\
\hline \multirow{3}{*}{$\begin{array}{l}\text { Pelaksanaan } \\
\text { penyuluhan }\end{array}$} & Rendah (skor 8-13) & 2 & \multirow{3}{*}{19,09} & 6,06 \\
\hline & Sedang (skor 14-19) & 14 & & 42,42 \\
\hline & Tinggi (skor 20-25) & 17 & & 51,52 \\
\hline \multirow[t]{3}{*}{ Evaluasi penyuluhan } & Rendah (skor 8-13) & 5 & \multirow{3}{*}{16,58} & 15,15 \\
\hline & Sedang (skor 14-19) & 22 & & 66,67 \\
\hline & Tinggi (skor 20-25) & 6 & & 18,18 \\
\hline \multirow[t]{3}{*}{ Pengembangan profesi } & Rendah (skor 8-13) & 4 & \multirow{3}{*}{16,94} & 12,12 \\
\hline & Sedang (skor 14-19) & 24 & & 72,73 \\
\hline & Tinggi (skor 20-25) & 5 & & 15,15 \\
\hline \multirow{3}{*}{$\begin{array}{l}\text { Komunikasi } \\
\text { penyuluhan }\end{array}$} & Rendah (skor 3-4) & 0 & \multirow{3}{*}{7,42} & 0 \\
\hline & Sedang (skor 5-6) & 2 & & 6,06 \\
\hline & Tinggi (skor 7-8) & 31 & & 93,94 \\
\hline
\end{tabular}

Sumber: Data primer diolah (2013)

Pada aspek komunikasi, tidak terdapat kendala bahasa bagi penyuluh sehingga dalam penyampaian materi dapat dimengerti oleh petani. Sebagian besar penyuluh mampu menggalang kerja sama yang baik terhadap petani dan rekan sejawat.

\section{Distribusi Penyuluh berdasarkan Produktivitas Kerja}

Mayoritas penyuluh pertanian Kota Bengkulu melakukan tatap muka dengan kelompok tani 6-10 kali setiap bulan. Model kunjungan yang dominan dilakukan oleh penyuluh adalah tatapmuka perorangan dengan mengunjungi pengurus kelompok tani dan petani maju. Kondisi ini senada dengan temuan Balitbang Jambi (2010). Metode penyuluhan yang dominan dilaksanakan oleh penyuluh di Kota Bengkulu adalah ceramah, diskusi, dan anjangsana. Namun beberapa penyuluh menggunakan media penyuluhan untuk meningkatkan efektifitas penyuluhan.

Sebagian besar wilayah binaan memiliki areal pertanian sempit sehingga didominasi satu jenis kelompok yaitu kelompok pengolahan hasil. Sehingga materi yang diberikan hanya berkisar tentang pengolahan hasil pertanian, pemanfaatan lahan pekarangan dan permodalan.

Hasil penelitian mengenai distribusi penyuluh berdasarkan Tingkat Produktivitas Kerja tersaji pada Tabel 4 berikut. 
ISSN: $1412-8837$

Tabel 4. Distribusi Penyuluh menurut Tingkat Produktivitas Kerja

\begin{tabular}{llccc}
\hline $\begin{array}{c}\text { Peubah } \\
(Y)\end{array}$ & \multicolumn{1}{c}{ Kategori } & $\begin{array}{c}\text { Jumlah } \\
\text { (orang) }\end{array}$ & Mean & $\begin{array}{c}\text { Persentase } \\
(\%)\end{array}$ \\
\hline Frekuensi kunjungan & Rendah (1-5 kali/bln) & 4 & & 12,12 \\
& Sedang (6-10 kali/bln) & 22 & 9,18 & 66,67 \\
& Tinggi (11-15 kali/bln) & 7 & & 21,21 \\
\hline Metode penyuluhan & Rendah (1-5 & 22 & & 66,67 \\
& metode/thn) & 11 & 4,42 & 33,33 \\
& Sedang (6-10 & 0 & & 0 \\
& metode/thn) & & & \\
& Tinggi (11-15 & & & \\
\hline Materi penyuluhan & Rendah (1-2 materi/bln) & 18 & & 54,55 \\
& Sedang (3-4 materi/bln) & 11 & 2,64 & 33,33 \\
& Tinggi (5-6 materi/bln) & 4 & & 12,12 \\
\hline Peningkatan & Rendah (1-33\%) & 20 & & 60,61 \\
pengetahuan petani & Sedang (34-67\%) & 11 & 31,52 & 33,33 \\
& Tinggi (68-100\%) & 2 & & 6,06 \\
\hline Peningkatan & Rendah (1-33\%) & 20 & & 60,61 \\
keterampilan petani & Sedang (34-67\%) & 11 & 30,45 & 33,33 \\
& Tinggi (68-100\%) & 2 & & 6,06 \\
\hline
\end{tabular}

Sumber: Data primer diolah (2013)

Dengan intensitas pelatihan rendah, kompetensi yang sedang atau kurang kompeten dan tingkat motivasi yang relatif cukup atau biasa saja serta proses penyuluhan yang dilakukan seadanya tanpa dukungan sarana dan prasarana yang memadai maka sudah dipastikan peningkatan pengetahuan petani yang dicapai rendah. Berdasarkan kondisi penyelenggaraan penyuluhan yang ada di Kota Bengkulu semua faktor yang menyebabkan rendahnya peningkatan pengetahuan petani juga berakibat yang sama terhadap peningkatan keterampilan petani.

\section{Hubungan antara Aspek-aspek Karakteristik Penyuluh dan Produktivitas Kerja Penyuluh}

Beberapa karakteristik penyuluh yaitu pelatihan, masa kerja, dan luas lahan pertanian wilayah kerja berkorelasi sangat nyata dengan produktivitas kerja penyuluh pertanian. Nilai koefisien korelasi yang ditunjukkan masingmasing faktor tersebut adalah pelatihan sebesar $0,604 p$-value $(0,000)$, masa kerja sebesar 0,574 p-value $(0,000)$, dan luas areal pertanian wilayah kerja sebesar 0,515 -value $(0,002)$; Korelasi karakteristik dan produktivitas penyuluh dapat dilihat pada tabel berikut ini. 
Tabel 5. Koefisien Korelasi antara Aspek-Aspek Karakteristik Penyuluh dengan Aspek-Aspek Produktivitas Kerja Penyuluh Pertanian

\begin{tabular}{|c|c|c|c|c|c|c|}
\hline $\begin{array}{r}\text { Peubah } \\
\text { produktivitas }\end{array}$ & $\begin{array}{c}\text { Fre } \\
\text { kuensi } \\
\text { kun- } \\
\text { jungan } \\
\text { (Y1) } \\
\end{array}$ & $\begin{array}{l}\text { Metode } \\
\text { Penyu- } \\
\text { luhan } \\
\text { (Y2) }\end{array}$ & $\begin{array}{c}\text { Materi } \\
\text { Penyu- } \\
\text { Luhan } \\
\text { (Y3) } \\
\end{array}$ & $\begin{array}{l}\text { Pening- } \\
\text { katan } \\
\text { penge- } \\
\text { tahuan } \\
(Y 4)\end{array}$ & $\begin{array}{l}\text { Pening- } \\
\text { katan } \\
\text { keteram- } \\
\text { pilan } \\
\text { (Y5) }\end{array}$ & $\begin{array}{l}\text { Produk- } \\
\text { tivitas } \\
\text { penyuluh } \\
(\mathrm{Y})\end{array}$ \\
\hline $\begin{array}{l}\text { Pendidikan formal } \\
\text { (X1.1) }\end{array}$ & 0,027 & $-0,023$ & $-0,032$ & 0,105 & 0,111 & 0,118 \\
\hline Pelatihan (X1.2) & $0,635^{* *}$ & $0,508^{* *}$ & 0,290 & $0,437^{*}$ & $0,444^{* *}$ & $0,604^{* *}$ \\
\hline Masa Kerja (X1.3) & $0,356^{*}$ & $0,422 *$ & $0,502^{* *}$ & $0,430^{*}$ & $0,443^{* *}$ & $0,574^{* *}$ \\
\hline $\begin{array}{l}\text { Jumlah Kelompok } \\
\text { tani binaan (X1.4) }\end{array}$ & 0,139 & 0,204 & 0,140 & 0,215 & 0,197 & 0,238 \\
\hline $\begin{array}{l}\text { Luas lahan pertanian } \\
\text { wilayah kerja (X1.5) }\end{array}$ & $0,366^{*}$ & $0,431^{*}$ & 0,234 & $0,414^{*}$ & $0,418^{*}$ & $0,515^{* *}$ \\
\hline
\end{tabular}

Sumber: Data primer diolah (2013)

Keterangan: **) nyata pada $\left.a=0,01 ;{ }^{*}\right)$ nyata pada $a=0,05$

Uji korelasi Pearson menunjukkan hasil bahwa pendidikan formal, tidak berkorelasi secara nyata dengan produktivitas kerja penyuluh. Tidak berkorelasinya secara nyata tingkat pendidikan formal dengan produktivitas kerja pada penelitian ini sejalan dengan hasil penelitian Hamzah (2011), Marius (2007), Suprijanto (2008) dan Samsualam, et al (2008). Tidak tampaknya korelasi nyata antara pendidikan formal dengan produktivitas kerja penyuluh diduga disebabkan oleh kualifikasi pendidikan untuk penyuluh baru merupakan pendidikan teknis pertanian, sehingga kemampuan dalam melakukan penyuluhan belum memadai. Sedangkan bagi penyuluh senior yang melanjutkan pendidikan ke perguruan tinggi terjebak pada tuntutan untuk penyesuaian ijazah. Hal ini senada dengan pendapat Hamzah (2011) dan Sumardjo (2012) dalam Huda et al (2009).

Faktor lainnya adalah penyuluh yang berpendidikan tinggi dan berpangkat cukup lebih rentan terhadap rasa tidak puas mengenai kondisi yang dialaminya sehingga banyak yang melakukan mutasi atau beralih profesi ke jabatan struktural, sedangkan yang berpendidikan rendah dan usia tinggi cenderung pasrah dan tidak lagi termotivasi meningkatkan kompetensi dan kinerjanya (Marius, 2007; Suhanda et al, 2008; Siregar dan Saridewi, 2010).

Hasil penelitian juga menunjukkan adanyakorelasi positif yang sangat nyata antara pelatihan dan produktivitas terutama pada aspek frekuensi kunjungan, metode penyuluhan, peningkatan pengetahuan dan keterampilan petani. Hal ini memberikan arti bahwa semakin tinggi frekuensi pelatihan yang diikuti seorang penyuluh maka semakin tinggi pula pemahaman dan penguasaan terhadap tugas pokok dan fungsi yang diembannya sehingga akan berpengaruh pada peningkatan kompetensi penyuluh dalam melaksanakan tugasnya (Leilani dan Amri, 2006). 
Penyuluh dengan penguasaan tugas yang lebih baik akan mempunyai kemampuan yang lebih baik dalam menghadapi petani binaan, dan kompetensi yang baik akan meningkatkan kepercayaan diri penyuluh dalam bekerja. Penyuluh dengan kompetensi dan kepercayaan diri tinggi akan lebih sering dalam melaksanakan kunjungan ke kelompok tani dan lebih mampu dalam merancang dan menerapkan metode penyuluhan yang tepat bagi petani binaannya. Jumlah kunjungan yang tinggi dan metode yang tepat akan meningkatkan pemahaman dan penerimaan petani terhadap diseminasi inovasi dan teknologi yang disampaikan penyuluh.

Korelasi yang positif dan sangat nyata juga ditunjukkan antara masa kerja penyuluh dengan semua aspek produktivitas kerja penyuluh. Masa kerja erat kaitannya dengan peningkatan dan penguasaan penyuluh terhadap tugas pokok dan fungsinya sehingga penyuluh yang lebih berpengalaman akan lebih produktif dalam menjalankan tugasnya. Dengan pengalaman yang cukup, seorang penyuluh lebih mudah berkomunikasi dengan petani, membaca dan menguasai kebutuhan lapangan serta memutuskan hal yang tepat dan penting untuk dilakukan. Penjelasan di atas senada dengan pendapat Leilani dan Amri (2006) serta Sapar (2011).

Penyuluh dengan masa kerja yang lama lebih mudah berinteraksi dengan petani yang tercermin dari jumlah kunjungan ke petani yang lebih banyak. Semakin berpengalaman seorang penyuluh maka semakin tinggi kreativitasnya dalam pelaksanaan penyuluhan sehingga metode dan materi yang diberikan lebih bervariasi dan lebih mampu menjawab kebutuhan petani. Hal ini akan berpengaruh pada peningkatan pengetahuan dan keterampilan petani. Kondisi ini sejalan dengan pendapat Hamzah (2011), bahwa kematangan usia dan pengalaman kerja membuat penyuluh lebih kreatif dalam membangun kerjasama untuk merencanakan program penyuluhan yang lebih partisipatif.

Sementara itu, hasil Uji korelasi Pearson menunjukkan jumlah kelompok tani binaan tidak berkorelasi nyata dengan produktivitas kerja penyuluh. Hasil penelitian ini sejalan dengan penelitian Hamzah (2011) yang menyatakan jumlah kelompok binaan menunjukkan hubungan yang tidak nyata dengan kinerja penyuluh. Jumlah kelompok tani tidak membuat frekuensi kunjungan penyuluh ke kelompok tani akan berubah. Hal ini diduga karena penyuluh kesulitan untuk mengumpulkan petani. Penyesuaian kegiatan penyuluhan dan kegiatan petani yang tidak mudah ditambah dengan masih banyak kelompok tani yang tidak memiliki jadwal pertemuan rutin (Badan Penelitian dan Pengembangan Provinsi Jambi, 2010; Muhsin, 2011).

Infrastruktur Kota Bengkulu yang cukup maju dan keberadaan Kota Bengkulu yang dekat dan terbuka dengan berbagai akses informasi, sehingga kebutuhan dalam usaha pertanian dan inovasi petani tidak bergantung pada penyuluh. Sebagaimana pendapat Istianingsih (2008) yang menyatakan infrastruktur yang cukup maju memudahkan masyarakat memenuhi 
kebutuhan dalam usaha pertanian, sehingga kegiatan-kegiatan kelompok tani dirasakan kurang bermanfaat.

Luas lahan pertanian wilayah kerja menunjukkan korelasi positif yang sangat nyata dengan produktivitas kerja penyuluh terutama pada aspek frekuensi kunjungan, metode penyuluhan, peningkatan pengetahuan dan keterampilan petani. Wilayah yang memiliki luas areal pertanian luas dianggap memiliki potensi agrbisnis yang lebih memadai, sehingga umumnya menjadi wilayah-wilayah yang masuk kedalam proyek-proyek pembangunan pertanian yang dikucurkan baik oleh pemerintah pusat maupun daerah. Daerah yang mendapat proyek dari pemerintah akan mendapatkan bantuan sarana maupun prasarana yang memudahkan penyuluh dalam melaksanakan diseminasi inovasi dan teknologi pertanian. Hal ini berdampak pada meningkatnya frekuensi kunjungan ke kelompok tani, peningkatan jumlah metode penyuluhan yang digunakan sehingga peningkatan pengetahuan dan keterampilan petani pun lebih baik.

Bagi penyuluh yang wilayah kerjanya kurang potensial, kurang mendapatkan dukungan sarana, baik untuk melaksanakan penyuluhan ataupun meningkatkan kompetensi penyuluh itu sendiri. Kondisi ini sesuai dengan pendapat Marius (2007) dan Sumardjo (2012) yang menyatakan keterbatasan sarana dan prasarana sangat dirasakan penyuluh terutama di wilayah yang dianggap kurang potensial bagi kegiatan pertanian, sehingga penyuluh menghadapi dilema besar karena di satu sisi berperan memberdayakan masyarakat namun sangat bergantung pada komitmen pemerintah. Hal ini berimbas pada semangat penyuluh dalam melaksanakan tugasnya

\section{Hubungan antara Aspek-aspek Motivasi Penyuluh dan Produktivitas Kerja Penyuluh}

Aspek-aspek motivasi yaitu pengakuan/penghargaan dan gaji/imbalan berkorelasi nyata dengan produktivitas kerja penyuluh pertanian. Nilai koefisien korelasi yang ditunjukkan masing-masing faktor adalah pengakuan/penghargaan sebesar 0,428 -value $(0,013)$ dan gaji/imbalan sebesar 0,470 p-value $(0,006)$.

Keinginan berprestasi penyuluh tidak berkorelasi nyata dengan produktivitas kerja penyuluh. Keinginan berprestasi penyuluh hanya berkorelasi nyata dengan aspek metode penyuluhan yang digunakan. Dalam melaksanakan penyuluhan, penyuluh yang memiliki keinginan berprestasi tinggi berupaya melibatkan berbagai pihak yang berkompeten dalam proses penyuluhan, sehingga metode penyuluhan yang digunakan pun lebih bervariasi. Namun keinginan berprestasi hanya sekadar slogan saat penyuluh merasakan usaha yang dilakukan tidak membawa manfaat bagi dirinya. Sistem penghargaan bagi penyuluh berprestasi selama ini seperti pemilihan penyuluh 
teladan dirasakan tidak transparan, dan manfaatnya juga tidak dirasakan oleh penyuluh. Dampak dari kondisi tersebut keinginan penyuluh berprestasi lebih diarahkan kepada hal-hal yang dapat mereka rasakan manfaatnya secara langsung, sehingga penyuluh lebih mengutamakan tugas-tugas administrasi dalam rangka pencapaian angka kredit yang cepat, untuk kenaikan jabatan fungsionalnya tugas di lapangan hanya dilakukan bila disertai dengan adanya program/proyek (Indraningsih et al, 2010).

Tabel 6. Koefisien Korelasi antara Fakto-Faktor Motivasi Penyuluh dengan Aspek-Aspek Produktivitas Kerja Penyuluh Pertanian

\begin{tabular}{|c|c|c|c|c|c|c|}
\hline $\begin{array}{l}\text { Peubah } \\
\text { produktivitas } \\
\text { Peubah } \\
\text { Motivasi }\end{array}$ & $\begin{array}{l}\text { Frekuensi } \\
\text { Kun- } \\
\text { jungan } \\
(\mathrm{Y} 1)\end{array}$ & $\begin{array}{l}\text { Metode } \\
\text { Penyu- } \\
\text { luhan } \\
\text { (Y2) }\end{array}$ & $\begin{array}{l}\text { Materi } \\
\text { Penyu- } \\
\text { luhan } \\
\text { (Y3) }\end{array}$ & $\begin{array}{l}\text { Peningkatan } \\
\text { pengeta- } \\
\text { huan } \\
(Y 4)\end{array}$ & $\begin{array}{l}\text { Peningkatan } \\
\text { keteram- } \\
\text { pilan } \\
\text { (Y5) }\end{array}$ & $\begin{array}{l}\text { Produk- } \\
\text { tivitas } \\
\text { penyuluh } \\
(\mathrm{Y})\end{array}$ \\
\hline Prestasi (X2.1) & 0,268 & $0,435^{*}$ & 0,241 & 0,173 & 0,197 & 0,320 \\
\hline $\begin{array}{l}\text { Pengakuan/ } \\
\text { penghargaan (X2.2) }\end{array}$ & 0,106 & 0,074 & $0,441^{*}$ & $0,456^{* *}$ & $0,441^{*}$ & $0,428^{*}$ \\
\hline Gaji/imbalan (X2.3) & 0,081 & 0,030 & $0,410^{*}$ & $0,547^{* *}$ & $0,541^{* *}$ & $0,470^{\star *}$ \\
\hline
\end{tabular}

Sumber: Data primer diolah (2013)

Keterangan: **) nyata pada $\left.a=0,01 ;{ }^{*}\right)$ nyata pada $a=0,05$

Uji korelasi Pearson menunjukkan korelasi positif dan nyata antara pengakuan/penghargaan dan produktivitas kerja penyuluh terutama pada aspek materi penyuluhan dan peningkatan pengetahuan serta keterampilan petani. Penyuluh yang merasa keberadaannya berharga bagi petani-petani di wilayah kerjanya cenderung meningkatkan kemampuan dan kreatifitasnya dalam bekerja, seperti penggunaan media dalam melaksanakan penyuluhan. Penggunaan media penyuluhan (leaflet, booklet, slide dan film) akan membantu penyuluh dalam mensintesakan materi penyuluhan yang diberikan sehingga materi yang diberikan lebih dapat dipahami oleh petani dan selanjutnya meningkatkan pengetahuan dan keterampilan petani. Sehingga, walaupun dengan keterbatasan metode dan frekuensi kunjungan, diseminasi teknologi dapat tercapai.

Hasil yang sama ditunjukkan oleh variabel gaji. Gaji/imbalan dorelasi positif dan sangat nyataan produktivitas kerja penyuluh terutama pada aspek materi penyuluhan dan peningkatan pengetahuan serta keterampilan petani, namun gaji/imbalan tidak berkorelasi nyata dengan aspek frekuensi kunjungan dan metode penyuluhan.

Penyuluh yang mempunyai keyakinan tinggi dan merasakan bahwa produktivitas kerjanya akan dihargai dengan kompensasi finansial yang sepadan akan berupaya memenuhi kewajibannya dalam melaksanakan tugas secara optimal dengan meningkatkan efektifitas kerja. Laporan Efektivitas 
Kerja Penyuluh Pertanian yang dikeluarkan Badan Penelitian dan Pembangunan Provinsi Jambi (2010) menyatakan terdapat indikasi bahwa penambahan insentif kepada penyuluh cenderung akan diiringi dengan peningkatan efektivitas kerjanya dalam menyelenggarakan kegiatan penyuluhan pertanian di lapangan. Selanjutnya Masno (2009) juga menyatakan kompensasi finansial merupakan salah satu faktor utama yang berperan dalam peningkatan produktivitas kerja.

Namun disisi lain karena gaji sebagian besar penyuluh telah dipotong bank, sehingga penyuluh memanfaatkan keleluasaan waktu dinasnya untuk mencari income tambahan diluar kegiatan menyuluh. Akibatnya penyuluh mengurangi frekuensi kunjungan ke kelompok tani dan mengggunakan metode penyuluhan yang mudah dilaksanakan. Kondisi ini senada dengan hasil penelitian Hariadi (2010), bahwa sumber penghasilan lain berpengaruh negatif terhadap produktivitas yang berarti semakin rendah sumber penghasilan lain (diluar penyuluh) maka semakin tinggi produktivitas kerja.

\section{Hubungan antara Aspek-aspek Kompetensi terhadap Produktivitas Kerja Penyuluh}

Aspek-aspek kompetensi penyuluh yaitu persiapan, pelaksanaan, evaluasi dan komunikasi berkorelasi positif dan sangat nyata dengan produktivitas kerja penyuluh pertanian. Nilai koefisien korelasi yang ditunjukkan masing-masing faktor tersebut adalah persiapan penyuluhan sebesar 0,456 -value $(0,008)$, pelaksanaan penyuluhan sebesar 0,446 -value $(0,009)$, evaluasi penyuluhan sebesar 0,451 -value $(0,008)$ dan komunikasi penyuluhan 0,544 -value $(0,001)$ Sementara pengembangan profesi justru berkorelasi negatif dan tidak nyata dengan produktivitas kerja penyuluh. Korelasi kompetensi penyuluh terhadap produktivitas kerja penyuluh dapat dilihat pada Tabel 7.

Kompetensi persiapan penyuluhan berkorelasi positif dan sangat nyata dengan produktivitas kerja penyuluh terutama pada aspek frekuensi kunjungan, dan materi penyuluhan. Kondisi ini berarti semakin kompeten seorang penyuluh dalam mempersiapkan penyuluhan maka frekuensi kunjungan yang dilakukan lebih terencana, terukur dan teratur, serta materi yang diberikan akan sesuai dengan kebutuhan dan potensi yang dimiliki wilayah binaannya.

Tidak berkorelasinya secara nyata kompetensi penyuluh dalam persiapan penyuluhan pada aspek metode penyuluhan yang digunakan, serta peningkatan pengetahuan dan keterampilan petani, diduga karena sebagian besar metode penyuluhan yang ada tidak dapat dilaksanakan oleh individu penyuluh sendiri. Metode penyuluhan tersebut harus melibatkan lintas sektoral serta membutuhkan alokasi dana serta sarana dan prasarana 
penunjang untuk dilaksanakan. Sehingga sering kali penggunaan metode yang telah direncanakan tidak sesuai dengan pelaksanaanya di lapangan dan banyak program/kegiatan yang direncanakan tidak dapat terealisasi dengan baik yang disebabkan faktor diluar kemampuan penyuluh ( Hamzah, 2011).

Tabel 7. Koefisien Korelasi antara Aspek-Aspek Kompetensi Penyuluh dengan Aspek-Aspek Produktivitas Kerja Penyuluh Pertanian

\begin{tabular}{|c|c|c|c|c|c|c|}
\hline 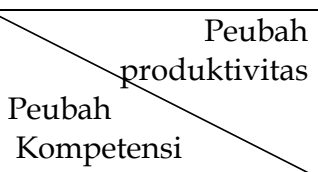 & $\begin{array}{l}\text { Frekuensi } \\
\text { kun- } \\
\text { jungan } \\
\text { (Y1) }\end{array}$ & $\begin{array}{l}\text { Metode } \\
\text { Penyu- } \\
\text { luhan } \\
\text { (Y2) }\end{array}$ & $\begin{array}{l}\text { Materi } \\
\text { Penyu- } \\
\text { luhan } \\
\text { (Y3) }\end{array}$ & $\begin{array}{l}\text { Peningkatan } \\
\text { penge- } \\
\text { tahuan } \\
(Y 4)\end{array}$ & $\begin{array}{l}\text { Peningkatan } \\
\text { keteram- } \\
\text { pilan } \\
(\mathrm{Y} 5)\end{array}$ & $\begin{array}{l}\text { Produk- } \\
\text { tivitas } \\
\text { penyuluh } \\
(\mathrm{Y})\end{array}$ \\
\hline $\begin{array}{l}\text { Persiapan } \\
\text { Penyuluhan } \\
\text { (X3.1) }\end{array}$ & $0,440^{*}$ & 0,294 & $0,569^{* *}$ & 0,267 & 0,239 & $0,456^{* *}$ \\
\hline $\begin{array}{l}\text { Pelaksanaan } \\
\text { Penyuluhan } \\
\text { (X3.2) }\end{array}$ & $0,473^{* *}$ & $0,481^{* *}$ & 0,277 & $0,353^{*}$ & $0,356^{*}$ & $0,446^{* *}$ \\
\hline $\begin{array}{l}\text { Evaluasi Penyuluhan } \\
\text { (X3.3) }\end{array}$ & $0,438^{*}$ & $0,402^{*}$ & $0,413^{*}$ & 0,265 & 0,273 & $0,451^{* *}$ \\
\hline $\begin{array}{l}\text { Pengembangan } \\
\text { Profesi } \\
\text { (X3.4) }\end{array}$ & 0,150 & 0,124 & 0,026 & $-0,132$ & $-0,146$ & $-0,054$ \\
\hline $\begin{array}{l}\text { Komunikasi } \\
\text { Penyuluhan } \\
\text { (X3.5) }\end{array}$ & $0,455^{* *}$ & $0,529^{* *}$ & $0,455^{* *}$ & $0,405^{*}$ & $0,416^{*}$ & $0,544^{* *}$ \\
\hline
\end{tabular}

Sumber: Data primer diolah (2013)

Keterangan: **) nyata pada $\left.a=0,01 ;{ }^{*}\right)$ nyata pada $a=0,05$

Kompetensi pelaksanaan penyuluhan berkorelasi positif dan sangat nyata dengan produktivitas kerja penyuluh terutama pada aspek frekuensi kunjungan, metode yang digunakan serta peningkatan pengetahuan dan keterampilan petani. Kondisi ini mengindikasikan semakin kompeten penyuluh pada aspek pelaksanaan penyuluhan maka semakin tinggi produktivitas kerjanya.

Penyuluh yang kompeten dalam aspek pelaksanaan penyuluhan akan mampu menumbuh kembangkan kelembagaan petani dengan baik. Kondisi ini memacu interaksi dengan petani lebih tinggi, sehingga dengan sendirinya frekuensi kunjungan penyuluh akan meningkat. Penyuluh ini juga mampu merancang dan melaksanakan metode penyuluhan yang bervariasi, baik secara langsung maupun tidak langsung, sesuai dengan kebutuhan dan sasaran yang ingin dicapai serta sumber daya yang dimilikinya. Penyampaian materi yang disertai dengan media penyuluhan menyebabkan peningkatan pengetahuan dan keterampilan petani lebih mudah dicapai.

Berdasarkan wawancara ternyata penyuluh yang memiliki kompetensi dalam aspek pelaksanaan penyuluhan akan memberikan materi yang lebih 
rinci dan detil, sedangkan penyuluh yang belum kompeten dalam pelaksanaan penyuluhan menyampaikan materi penyuluhan bersifat lebih umum, sehingga terkadang jumlah materi yang disampaikan penyuluh yang kompeten dalam aspek pelaksanaan lebih sedikit dibanding dengan penyuluh biasa.

Kompetensi evaluasi penyuluhan berkorelasi positif dan sangat nyata dengan produktivitas kerja penyuluh terutama pada aspek frekuensi kunjungan, metode penyuluhan yang digunakan serta materi penyuluhan yang diberikan. Penyuluh pertanian yang kompeten dalam melaksanakan evaluasi penyuluhan akan mampu mengetahui kelemahan-kelamahan dalam proses pelaksanaan tugas yang telah dilaksanakannya. Hal ini sesuai dengan pendapat Hamzah (2011) yang menyatakan "Penyuluh yang sering melakukan evaluasi berarti penyuluh tersebut akan mampu mempertahankan prestasi kerjanya atau memperbaiki hasil kerja sebelumnya sehingga menjadi lebih baik".

Penyuluh yang kompeten melakukan evaluasi dapat mengetahui frekuensi kunjungan yang tepat untuk dilaksanakan, serta metode dan materi yang dibutuhkan oleh petani binaanya. Namun hal ini kadang belum mampu meningkatkan pengetahuan dan keterampilan petani secara signifikan, karena disebabkan banyak rencana tindak lanjut yang tidak bisa terlaksana secara optimal. Hasil evaluasi terkadang tidak bisa dilaksanakan dengan baik apabila sudah berkaitan dengan dukungan organisasi dan kebijakan pemerintah.

Kompetensi Pengembangan profesi berkorelasi negatif dan tidak nyata dengan produktivitas kerja penyuluh. Ini berarti semakin kompeten seorang penyuluh dalam pengembangan profesi maka produktivitas kerjanya akan cenderung rendah. Hal ini diduga karena tugas pokok penyuluh pertanian dalam pengembangan profesi adalah membuat karya tulis ilmiah baik yang terpublikasi ataupun tidak, membuat saduran ataupun terjemahan yang terpublikasi ataupun tidak serta memberikan konsultasi kepada petani dan institusi tertentu.

Berdasarkan Peraturan Menteri Negara Pendayagunaan Aparatur Negara Nomor: PER/02/MENPAN/2/2008 tentang Jabatan Fungsional Penyuluh Pertanian dan Angka Kreditnya serta Peraturan Menteri Pertanian Nomor 35/Permentan/OT.140/7/2009 tentang Petunjuk Teknis Pelaksanaan Jabatan Fungsional Penyuluh Pertanian dan Angka Kreditnya bahwa angka kredit yang dihasilkan dari aspek pengembangan profesi jauh lebih besar dari pada angka kredit yang diperoleh dari pelaksanaan tugas pokok penyuluh yang lain.

Penyuluh yang kompeten dalam pengembangan profesi akan lebih fokus dalam membuat tulisan ilmiah, saduran/terjemahan dibidang pertanian dari pada melaksanakan tugas lapangan penyuluhan yang nilai kreditnya jauh lebih kecil dan lebih menguras tenaga. Selain itu penyuluh yang mempunyai jabatan penyuluh madya ataupun berpangkat IV/a keatas diwajibkan mengumpulkan paling kurang 12 (dua belas) angka kredit dari kegiatan penulisan karya tulis 
ilmiah. Semakin kompeten penyuluh dalam kegiatan pengembangan profesi semakin kurang kegiatan lapangan penyuluh yang bersentuhan langsung dengan petani sehingga peningkatan pengetahuan dan keterampilan petani semakin rendah.

Kompetensi komunikasi penyuluh pertanian berkorelasi positif dan sangat nyata dengan. semua aspek produktivitas. Hal ini berarti semakin tinggi dan efektif kemampuan komunikasi penyuluh baik terhadap atasan, rekan sejawat dan petani binaan, maka semakin tinggi produktivitas kerja penyuluh tersebut. Kompetensi komunikasi akan menimbulkan kemampuan menggalang kerjasama baik secara horizontal maupun vertikal dalam rangka pencapaian tujuan. Semakin baik dan efektif kompetensi komunikasi penyuluh maka interaksi dengan petani akan meningkat sehingga penyuluh dapat lebih mengenal dan mengetahui kebutuhan petani binaannya.

Dalam proses penguasaan materi bahan ajar ataupun menjawab persoalan-persoalan teknis di lapangan kemampuan komunikasi penyuluh terhadap rekan sejawat memegang peranan penting. Hal ini sebagaimana yang dinyatakan Huda et al (2009) bahwa "semakin tinggi tingkat interaksi penyuluh dengan sejawat dalam kelompok belajar, akan semakin intensif diskusi tentang materi bahan ajar sehingga bierdampak pada peningkatan kompetensinya". Penyuluh yang memiliki kompetensi komunikasi yang baik, maka proses penyampaian materi akan bersifat dua arah dan komunikatif, sehingga maksud dan tujuan materi yang diberikan akan lebih mudah dicerna.

Kompetensi komunikasi juga mempunyai andil terhadap metode-metode yang dapat digunakan penyuluh, karena sebagian besar metode penyuluhan merupakan pekerjaan lintas instansi dan membutuhkan dukungan dana ataupun kebijakan dari atasan.

\section{KESIMPULAN DAN SARAN}

\section{Kesimpulan}

Kesimpulan yang dapat ditarik dari penelitian ini adalah:

1. Penyuluh pertanian Kota Bengkulu mayoritas memiliki motivasi berprestasi yang tinggi, namun merasa mendapat pengakuan ataupenghargaan pada kategori sedang serta keyakinan mendapatkan imbalan yang sepadan terhadap hasil kerjanya cenderung rendah.

2. Penyuluh Pertanian Kota Bengkulu mayoritas memiliki kompetensi tinggi pada komunikasi, persiapan dan pelaksanaan penyuluhan, namun memiliki kompetensi evaluasi penyuluhan dan pengembangan profesi tingkat sedang, namun memiliki produktivitas kerja penyuluh pertanian yang rendah. 
3. Karakteristik penyuluh yang berkorelasi nyata dan sangat nyata dengan produktivitas kerja adalah pelatihan, masa kerja, dan luas lahan pertanian wilayah kerja, sedangkan motivasi yang berkorelasi nyata dan sangat nyata dengan produktivitas kerja adalah pengakuan/penghargaan dan gaji/imbalan.

4. Kompetensi yang berkorelasi nyata dan sangat nyata dengan produktivitas kerja adalah persiapan, pelaksanaan, evaluasi dan komunikasi penyuluhan.

\section{Saran}

1. Diperlukan intensitas pelatihan yang tinggi dan merata kepada semua penyuluh pertanian Kota Bengkulu baik teknis maupun sosial ekonomi.

2. Penerapan reward dan punishment untuk memacu motivasi kerja penyuluh pertanian sehingga dapat meningkatkan produktivitas kerja, serta sarana dan prasarana serta dana pendukung yang memadai untuk penyelenggaraan kegiatan penyuluhan yang optimal.

\section{DAFTAR PUSTAKA}

Anonim. 2010. Dasar-dasar Penyuluhan Pertanian. Modul Diklat Fungsional Penyuluh Pertanian Ahli. Badan Pengembangan Sumber Daya Manusia Pertanian, Kementerian Pertanian Republik Indonesia. Jakarta.

[Badan Penelitian dan Pengembangan Provinsi Jambi].2010. Laporan Penelitian Efektivitas Kerja Penyuluh Pertanian Lapangan. http:/ /litbangjambi11.files.wordpress.com/2011/07/laporan-akhirefektivitas-kerja-ppl3.pdf. Diakses tanggal 23 Desember 2012.

Hamzah, I. 2011. Faktor Penentu Kinerja Penyuluh Pertanian di Kota Tidore Kepulauan Provinsi Maluku Utara. Unpublished Tesis. Sekolah Pasca Sarjana Institut Pertanian Bogor. Bogor.

Hariadi, S.S. 2010. Sertifikasi, Disiplin, dan Produktivitas Kerja Penyuluh Pertanian. Jurnal Ilmu-ilmu Pertanian. 6 (1) : 1-9.

Hubeis, A., Vitayala. 2007. Motivasi, Kepuasan Kerja dan Produktivitas Penyuluh Pertanian Lapangan: Kasus Kabupaten Sukabumi. Jurnal Penyuluhan. 3 (2) : 90-99.

Huda, N., Sumardjo, M. Slamet, dan P. Tjitropranoto. 2009. Pengembangan Kompetensi Penyuluh Pertanian dalam Pendidikan Jarak Jauh Universitas Terbuka (UT): Kasus Alumni UT di wilayah Serang, Karawang, Cirebon dan Tanggamus. Jurnal Komunikasi Pembangunan. 7 (2) : 1-31. 
Indraningsih, K.S., B.G. Sugihen, P. Tjitropranoto, Pang S., Asngari, dan H.I. Wijayanto. 2010. Kinerja Penyuluh dari Perspektif Petani dan Eksistensi Penyuluh Swadaya Sebagai Pendamping Penyuluh Pertanian. Analisis Kebijakan Pertanian. 8 (4) : 303-321.

Istianingsih. 2008. Kinerja Penyuluh Pertanian Kabupaten Kulon Progo, Gunungkidul, Sleman dan Bantul di Era Otonami Daerah. Jurnal Ilmuilmu Pertanian. 4 (1) : 20-37.

[Kementerian Pertanian]. 2009. Peraturan Menteri Pertanian tentang Petunjuk Teknis Pelaksanaan Jabatan Fungsional Penyuluh Pertanian dan Angka Kreditnya. Kementerian Pertanian Republik Indonesia. Jakarta.

Leilani, A. dan Amri Jahi. 2006. Kinerja Penyuluh Pertanian di Beberapa Kabupaten Provinsi Jawa Barat. Jurnal Penyuluhan. 2 (2) : 99-105.

Marius, J.A. 2007. Pengembangan Kompetensi Penyuluh Pertanian di Provinsi Nusa Tenggara Timur. Unpublished Disertasi. Sekolah Pasca Sarjana Institut Pertanian Bogor. Bogor.

Masno. 2010. Faktor Faktor Yang Mempengaruhi Terhadap Produktivitas Kerja Pegawai Pada Kantor Badan Keluarga Berencana Kota Makassar. Jurnal Economic Resources. 11 (31) : 161-178.

Muhsin. 2011. Peranan dan Fungsi Penyuluh Kehutanan Dalam Pengembangan Kelompok Tani di Kabupaten Lombok Barat. GaneC Swara. 5 (1) : 63-78.

Sapar. 2011. Faktor - Faktor Yang Memengaruhi Kinerja Penyuluh Pertanian dan Dampaknya pada Kompetensi Petani Kakao di Empat Wilayah Sulawesi Selatan. Unpublished Disertasi. Sekolah Pasca Sarjana Institut Pertanian Bogor. Bogor.

Samsualam, Indar, dan Muh. Syafar. 2008. Analisis Hubungan Karakteristik Individu dan Motivasi Dengan Kinerja Asuhan Perawatan di BP. Rumah Sakit Umum Labuang Baji Makassar. Jurnal Kesehatan Masyarakat Madani. 1 (2) : 1-9.

Siregar, A.N. dan Saridewi, T.R. 2010. Hubungan Antara Motivasi dan Budaya Kerja dengan Kinerja Penyuluh Pertanian di Kabupaten Subang, Provinsi Jawa Barat. Jurnal Penyuluhan Pertanian. 5 (1) : 24-35.

Suhanda, N.S, Amri Jahi, B.G. Sugihen dan Djoko Susanto. 2008. Kinerja Penyuluh Pertanian di Jawa Barat. Jurnal Penyuluhan. 4 (2) : 100-108.

Sumardjo. 2012. Review dan Refleksi Model Penyuluhan dan Inovasi Penyuluhan Masa Depan. http://care.ipb.ac.id/index.php/in/ publikasi/artikel?download=17\%3Arefleksi-dan-review-model. Diakses tanggal 15 Januari 2013.

Suprijanto. 2008. Hubungan antara Tingkat Pendidikan Formal dan Faktor Psikolgis dengan Kinerja Penyuluh Pertanian Lapangan (Studi Kasus di Kabupaten Banjar). Jurnal Agrin. 12 (1) : 114-127.

84 | M. Ali Hanafiah, Witman Rasyid, Agus Purwoko, Hubungan Karakt.... 